\title{
The Role of Student's Parents in Education at Public Elementary School 3 of Jatiluhur
}

\section{Dwi Purwanti}

SD Negeri 3 Jatiluhur Karanganyar Kebumen

dpurwanti1976@gmail.com

\begin{tabular}{lll}
\hline Article History & approved 01/10/2019 & published 01/12/2019 \\
accepted 24/09/2019
\end{tabular}

\begin{abstract}
Educational development in Indonesia needs the participation of parents and the community and the school itself. These three elements must work together in an effort to realize the goals of education in schools. Parents of students were originally only concentrated in supporting the education of children in the family, now it is developing in the involvement of parents in the administration of education in schools, including those that occur in SD Negeri 3 Jatiluhur. This study focuses on: (1) what is the role of parents in education ?; (2) what is the form of parental participation in SD Negeri 3 Jatiluhur? The results of this study include: (1) the participation of parents in education, namely the involvement of parents in organizing their children's education in schools; (2) the form of parental participation in SD Negeri 3 Jatiluhur is to attend meetings held by the school, attend the parent / guardian class, become a member of the school committee, as a companion to extracurricular activities, play an active role in the activities carried out by the school committee, play an active role in the activities of Strengthening Children's Character Education in schools.
\end{abstract}

Keywords: parental participation, education, elementary school

\section{Abstrak}

Masuknya era revolusi industri 4.0 memberikan tantangan yang sangat besar bagi masyarakat Indonesia. Salah satu tantangan tersebut adalah globalisasi. Globalisasi menjadikan persaingan di segala bidang kehidupan masyarakat menjadi semakin besar, termasuk bidang pendidikan. Guru sebagai garda terdepan di bidang pendidikan memiliki peran utama dalam berhasilnya sebuah sistem pendidikan, karena kegiatan pembelajaran yang diikuti siswa sangat dipengaruhi oleh kompetensi guru. Guru memiliki peran yang sangat strategis di bidang pendidikan, bahkan sumber referensi lain yang dianggap memadai sering kali menjadi tidak berarti apabila tidak didukung adanya seorang guru berkualitas. Kemampuan dasar siswa seperti membaca, menulis, dan berhitung mutlak tidak lagi cukup untuk dapat bersaing di era revolusi industri 4.0 dengan segala tantangannya. Oleh karena itu, pendidikan yang dilaksanakan harus menyiapkan siswa agar mampu bersaing di masyarakat global. Untuk itulah guru harus mampu beradaptasi dengan segala bentuk perubahan yang terjadi. Pada era ini, guru harus memiliki keterampilan yang dibutuhkan untuk menghadapi perubahan yang serba cepat ini.

Kata kunci: Keterampilan Guru SD, Era Revolusi Industri 4.0.

Social, Humanities, and Education Studies (SHEs): Conference Series https://jurnal.uns.ac.id/shes

p-ISSN 2620-9284

e-ISSN 2620-9292 


\section{PENDAHULUAN}

Mempersiapkan sumber daya manusia (SDM) yang berkualitas, memiliki kompetensi, berkarakter dan berdaya saing tinggi adalah tujuan dari pendidikan nasional. UUSPN nomor 20 tahun 2003 mengisyaratkan bahwa pendidikan merupakan tanggung jawab bersama antara unsur keluarga, masyarakat dan pemerintah. Ketiga unsur ini dinamakan tri pusat pendidikan. Unsur keluarga dalam hal ini adalah orang tua, merupakan tempat pertama dan utama bagi anak dalam memperoleh pendidikan. Melalui orang tua, diharapkan anak dapat tumbuh serta berkembang sesuai dengan kemampuannya untuk menjadi mandiri dan produktif bagi diri sendiri dan lingkungannya.

Mencuplik pendapat Riana (2012), bahwa orang tua memiliki peranan penting untuk memberikan dasar pendidikan, sikap serta keterampilan dasar, seperti: pendidikan agama, budi pekerti, sopan santun, estetika, kasih sayang, rasa aman, dasar-dasar untuk mematuhi peraturan-peraturan, dan menanamkan kebiasaankebiasaan. Orang tua juga memiliki kewajiban untuk mengajarkan kepada anak-anak tentang nilai-nilai dan tingkah laku sesuai dengan norma yang berlaku di masyarakat. Namun sayangnya orang tua belum siap menjadi pendidik bagi anak-anaknya. Orang tua harus mencari sendiri informasi dan pengetahuan tentang bagaimana menumbuhkan dan mendukung pendidikan anak-anak mereka.

Sampai saat ini, ketika kita memperbincangkan tentang pendidikan, maka fokus perbincangan terkonsentrasi kepada siswa dan guru, sementara orang tua seperti diabaikan. Kenyataannya orang tua juga ikut bertanggung jawab atas pendidikan anak mereka, baik di rumah maupun di sekolah. Bentuk pertanggungjawaban orang tua dalam pendidikan diwujudkan dengan peran serta yang harmonis antara orang tua, sekolah, dan masyarakat sebagai tri pusat pendidikan.

Sejalan dengan pendapat tersebut, Raraswati (2016) mengungkapkan tentang alasan pentingnya kemitraan antara sekolah dengan orang tua, yaitu; (1) orang tua sebagai pendidik pertama dan utama, tetapi dalam kenyatannya sebagian besar orang tua menyerahkan sepenuhnya tanggung jawab pendidikan anak pada sekolah; (2) peran sekolah adalah membantu orang tua agar pelaksanaan pendidikan lebih sistematis, efektif dan hasilnya tersertifkasi; (3) tidak semua kebutuhan pendidikan anak dapat dipenuhi oleh sekolah maupun orang tua; (4) kerjasama orang tua dengan sekolah mutlak diperlukan; (5) sekolah wajib mendorong kemitraan dan pelibatan orang tua dalam memajukan pendidikan anak mereka.

Kemendikbud (2016) menyatakan bahwa banyak penelitian yang menunjukkan manfaat keterlibatan orang tua di sekolah, antara lain: (1) bagi peserta didik dapat mendukung prestasi akademik, meningkatkan kehadiran, kesadaran terhadap kehidupan yang sehat, dan meningkatkan perilaku positif; (2) bagi orang tua dapat memperbaiki pandangan terhadap sekolah, meningkatkan kepuasan terhadap guru, dan mempererat hubungan dengan anak; dan (3) bagi sekolah dapat memperbaiki iklim sekolah, meningkatkan kualitas sekolah, dan mengurangi masalah kedisiplinan.

Senada yang disampaikan Lickona (2013) yang menyatakan bahwa meskipun sekolah mampu meningkatkan pemahaman awal para siswanya ketika mereka ada di sekolah, kemudian bukti-bukti yang ada menunjukkan bahwa sekolah mampu melaksanakan hal tersebut, sikap baik yang dimiliki oleh anak-anak tersebut perlahan akan menghilang jika nilai-nilai yang diajarkan di sekolah tersebut tidak mendapatkan dukungan dari lingkungan rumah.

Mendasari berbagai pendapat dari yang telah diuraikan di atas maka dapat disimpulkan bahwa antara sekolah dan orang tua harus seiring sejalan dalam menyikapi masalah yang muncul. Oleh karena itu diperlukan peran serta orang tua dalam pendidikan di sekolahnya. Salah satu peran serta orang tua terhadap pendidikan anaknya adalah dengan melibatkan diri dalam kegiatan pendidikan di sekolah anaknya. Peran serta orang tua dalam pendidikan di sekolah dapat memberi 
kontribusi yang positif baik kepada siswa maupun sekolah. Peran serta orang tua tersebut juga terjadi di SD Negeri 3 Jatiluhur, diantaranya orang tua aktif menghadiri pertemuan yang diselenggarakan oleh sekolah, mengikuti kelas orang tua/wali, menjadi anggota komite sekolah, sebagai pendamping kegiatan ekstrakurikuler, berperan aktif dalam kegiatan yang diselenggarakan oleh komite sekolah, berperan aktif dalam kegiatan Penguatan Pendidikan Karakter Anak di sekolah.

Berdasarkan uraian tersebut maka dalam kajian ini akan dibahas tentang peran serta orang tua murid dalam pendidikan di SD Negeri 3 Jatiluhur. Fokus kajian ini berupa: 1) peran serta orang tua murid dalam pendidikan; (2) bentuk peran serta orang tua murid di SD Negeri 3 Jatiluhur.

\section{HASIL DAN PEMBAHASAN}

\section{Peran serta orang tua murid dalam pendidikan}

Ada tiga komponen yang ikut bertanggung jawab ataskebrehasilan pendidikan terhadap anak, yaitu orang tua, sekolah dan masyarakat yang kita sebut dengan tri pusat pendidikan. Tiga komponen tersebut saling mempengaruhi dalam pembentukan kepribadian serta tingkah laku anak. Komponen pertama yaitu orang tua, mau tidak mau, mempunyai keahlian ataupun tidak, berkewajiban secara kodrati untuk menyelenggarakan pendidikan terhadap anak-anaknya. Pendidikan yang diberikan oleh orang tua berlangsung secara alamiah dan wajar atau sering disebut dengan pendidikan informal. Komponen ke dua yaitu sekolah, merupakan lembaga pendidikan formal yang bertugas untuk menambah ilmu pengetahuan dan kecerdasan akal. Komponen ke tiga adalah masyarakat, yaitu perkumpulan manusia yag hidup bersama di suatu tempat dengan ikatan-ikatan aturan tertentu yang saling membutuhkan. Ketiga komponen tersebut saling berkaitan dalam pendidikan anak.

Anak dilahirkan di lingkungan keluarga dan mendapatkan pendidikan dari orang tua. Seiring berjalannya waktu, anak tidak hanya membutuhkan pendidikan informal melainkan juga pendidikan formal yaitu sekolah. Hal tersebut memberikan sinyal bahwa orang tua harus menyadari bahwa sekolah hanyalah pembantu kelanjutan pendidikan anak dari orang tuanya. Jadi disini proses peralihan pendidikan dari jalur informal ke jalur formal yaitu sekolah memerlukan peran serta antara orang tua dan sekolah.

Peran serta yang positif dari orang tua sangat diperlukan dalam mendidik anakanak mereka. Peran serta orang tua dalam mendidik anak merupakan kunci keberhasilan orang tua dalam membentuk kepribadian anak. Anak cenderung meniru setiap hal yang dilihat dari orang tuanya. Anak mengikuti perintah dari yang diajarkan oleh orang tuanya. Begitu juga nantinya, sikap anak terhadap sekolah akan dipengaruhi oleh sikap orang tuanya. Oleh karena itu Kepercayaan orang tua terhadap sekolah sangat diperlukan dalam menggantikan tugasnya selama di ruangan sekolah.

Mencuplik pendapat beberapa ahli, bahwa orang tua yang terlibat dalam pendidikan di sekolah juga diyakini memiliki hubungan positif terhadap kolaborasi antara sekolah dengan orang tua serta bentuk konstruksi peran aktif orang tua dalam pendidikan anak-anak di sekolah (Scribner, Young, \& Pedroza, 1999). Raraswati (dalam Ihat) juga memaparkan tentang peran orang tua, diantaranya: (a) menciptakan lingkungan belajar di rumah yang menyenangkan, menumbuhkan budi pekerti, dan budaya prestasi; (b) menjalin interaksi dan komunikasi yang hangat dan penuh kasih sayang dengan anak; (c) memberikan motivasi yang menumbuhkan rasa percaya diri pada anak; (d) menjalin hubungan aktif dengan pihak sekolah untuk menciptakan lingkungan belajar yang kondusif; dan (e) berpartisipasi aktif dalam kegiatan keluarga di sekolah.

Berdasarkan pemikiran para ahli di atas dapat disimpulkan bahwa peran serta orang tua adalah keterlibatan orang tua dalam berbagai kegiatan di sekolah dalam rangka memberikan dukungan terhadap kegiatan belajar anak di sekolah. Peran serta 
orang tua dalam pendidikan di sekolah di seluruh tingkatan, kelompok etnis dan budaya bisa memberikan dampak positif pada kinerja siswa di sekolah, baik kinerja akademis maupun non akademis.

Orang tua memiliki peran yang tinggi dalam peningkatan pembelajaran anak di sekolah. Peran tersebut bukan hanya semata-mata membiayai pendidikan, namun lebih meluas pada memberikan dukungan secara moril maupun materiil terhadap kegiatan belajar anak di sekolah. Hal tersebut sesuai dengan Permendikbud Nomor 30 tahun 2017 yang mengisyaratkan tentang proses atau cara orang tua untuk berperan serta dalam penyelenggaraan pendidikan guna mencapai tujuan pendidikan nasional.

Juknis kemitraan sekolah dasar dengan keluarga dan masyarakat yang disusun oleh Dirjen PAUD dan pendidikan masyarakat Direktorat Pembinaan dan Pendidikan Keluarga Tahun 2016 juga menyebutkan bahwa orang tua memiliki peran sangat besar dalam pendidikan anak. Keberhasilan pendidikan anak bergantung kepada keterlibatan orang tua. Peran serta orang tua mempunyai beberapa tujuan, yaitu untuk: (a) meningkatkan kepedulian dan tanggung jawab bersama antara sekolah, orang tua, dan masyarakat terhadap penyelenggaraan pendidikan; (b) mendorong penguatan pendidikan karakter anak; (c) meningkatkan kepedulian orang tua terhadap pendidikan anak; (d) membangun sinergitas antara sekolah, orang tua, dan masyarakat; serta (e) mewujudkan lingkungan sekolah yang aman, nyaman, dan menyenangkan.

Secara garis besar tujuan dari peran serta orang tua dalam pendidikan di sekolah adalah untuk mewujudkan kerjasama dan keselarasan program pendidikan di sekolah, keluarga, dan masyarakat sebagai tri sentra pendidikan dalam membangun ekosistem pendidikan yang menumbuhkan karakter dan budaya berprestasi peserta didik. Dengan adanya peran serta orang tua dalam pendidikan di sekolah, diharapkan ada dampak yang muncul, diantaranya: (1) meningkatkan kehadiran anak di sekolah; (2) meningkatkan sikap dan perilaku positif anak; (3) meningkatkan kebiasaan belajar anak; (4) meningkakan prestasi akademik anak; (5) meningkatkan keinginan anak untuk melanjutkan sekolah; (6) meningkatkan komunikasi antara orang tua dan anak; (7) meningkatkan harapan orang tua pada anak; (8) orang tua merasa turut berhasil; (9) meningkatkan kepuasan orang tua terhadap sekolah; (10) meningkatkan semangat kerja guru; (11) mendukung iklim sekolah yang lebih baik; (12) mendukung kemajuan sekolah secara keseluruhan (Sukiman. 2017:10).

Pentingnya peran serta orang tua mengharuskan sekolah untuk meminta masukan dari orang tua. Masukan tersebut bisa dalam penyusunan program yang relevan, dan yang tidak kalah penting adalah dukungan orang tua dalam melaksanakan program tersebut. Di sisi lain, orang tua juga memerlukan jasa sekolah untuk mendapatkan program-program pendidikan sesuai dengan yang diinginkan. Peran serta orang tua dalam pendidikan anak di sekolah sangat berpengaruh pada keberhasilan anak maupun sekolah itu sendiri. Orang tua juga dapat memantau perkembangan anak dari sisi penerimaan ilmu pengetahuan, perkembangan mental dan karakter. Dengan adanya peran serta dari orang tua dalam kegiatan di sekolah dapat dikatakan sebagai proses meningkatkan kualitas sekolah itu sendiri.

\section{Bentuk peran serta orang tua di SD Negeri 3 Jatiluhur}

Seperti sudah disampaikan di atas, bahwa peran serta orang tua murid dalam pendidikan di sekolah memiliki arti yang sangat luas. Hal ini bukan berarti orang tua turut masuk ke sekolah atau kelas dan ikut mencampur program kelas maupun sekolah. Namun program kelas maupun sekolah dapat dilakukan berdasarkan usulan dari orang tua murid.

Dalam rangka mengaktifkan peran serta orang tua, sekolah merancang sekaligus menerapkan kegiatan yang melibatkan peran serta orang tua. Peran serta yang diharapkan oleh sekolah berdasarkan pada tujuan yang hendak dicapai oleh sekolah dalam proses pendidikan di sekolah. Kita pasti setuju bahwa tujuan yang ingin dicapai sekolah pada hakikatnya adalah tujuan pendidikan secara nasional, yang terdiri dari 
unsur-unsur: (1) manusia yang bertaqwa, berbudi pekerti dan berkepribadian; (2) disiplin, bekerja keras, bertanggung jawab serta mandiri; (3) cerdas dan terampil; (4) sehat jasmani dan rohani; (5) cinta tanah air dan mempunyai semangat kebangsaan serta kesetiakawanan sosial.

Sebagaimana dalam pasal 6 Permendikbud Nomor 30 tahun 2017 telah dirinci bentuk peran serta orang tua dalam pendidikan di sekolah. Bentuk peran serta yang diinginkan sekolah dari orangtua murid adalah untuk meningkatkan prestasi akademik dan non akademik siswa. Semua akan terwujud jika orang tua mempunyai cara pandang sekolah adalah lembaga yang memiliki cara kerja. Cara kerja sekolah tersebut harus meyakinkan dalam membina perkembangan anak-anak mereka. Jika hal demkian telah terpenuhi, maka orang tua akan aktif berperan serta dalam kegiatan sekolah. Sekolah dan orang tua juga harus aktif berkomunikasi untuk meningkatkan peran serta. Komunikasi tentang pendidikan kepada orang tua tidak cukup hanya dengan informasi verbal saja, tetapi perlu dilengkapi dengan pengalaman nyata yang berupa prestasi.

SD Negeri 3 Jatiluhur juga telah menumbuhkan peran serta orang tua murid dalam pendidikan. Adapun bentuk peran serta orang tua murid yang telah dijalankan oleh SD Negeri 3 Jatiluhur sesuai dengan Bab III Pasal 6 Permendikbud Nomor 30 tahun 2017 diantaranya adalah: (1) menghadiri pertemuan yang diselenggarakan oleh sekolah; (2) mengikuti kelas orang tua/wali; (3) menjadi anggota komite sekolah; (4) sebagai pendamping kegiatan ekstrakurikuler; (5) berperan aktif dalam kegiatan yang diselenggarakan oleh komite sekolah; (6) berperan aktif dalam kegiatan Penguatan Pendidikan Karakter Anak di sekolah.

Hal ini sejalan dengan penelitian milik Patrikakou (dalam Murwatiningsih, 2017: 104), "Pelibatan orangtua berarti partisipasi orangtua secara regular, dua arah, dan komunikasi penuh makna terlibat dalam pembelajaran akademik siswa dan aktivitas sekkolah lainnya termasuk di dalamnya adalah memastikan bahwa (a) orangtua memainkan tanggungjawab dalam menyertai belajar anak-anak mereka, (b) orangtua berani untuk aktif terlibat dalam pendidikan anak mereka di sekolah, dan (c) orangtua menjadi rekan yang sepenuhnya telibat dalam pendidikan anak-anak mereka, seperti dalam pengambilan keputusan dan dalam komite penasihat untuk memandu pada pendidikan anak-anak mereka".

Peran serta orang tua murid di SD Negeri 3 Jatiluhur dalam menghadiri pertemuan yang diselenggarakan oleh sekolah, adalah ketika sekolah mengadakan pertemuan untuk menyampaikan laporan pertanggung jawaban kerja sekolah serta sosialisasi program sekolah. Orang tua terlibat dalam kegiatan tersebut, mereka mengapresiasi atas keberhasilan prestasi yang telah dicapai oleh sekolah pada tahun yang telah berlalu. Sebaliknya, sekolah mensosialisasikan program selama satu tahun ke depan guna mendapat dukungan dari orang tua.

Peran serta orang tua mengikuti kegiatan kelas orang tua adalah aktif dalam pertemuan paguyuban yang diselenggarakan sebulan sekali sesuai jadwal yang telah disepakati. Dalam kegiatan paguyuban dibahas tentang perkembangan siswa selama satu bulan terakhir di sekolah. Orang tua juga bisa menanyakan hak-hak anak dalam belajar. Kegiatan lainnya adalah mengikuti kegiatan parenting wali murid yang diisi oleh psikolog yang telah bekerjasama dengan sekolah. Kegiatan parenting ini membekali orang tua dalam mengasuh anak-anak mereka. Hal ini sejalan dengan penelitian Prabhawani (2016) yang berjudul Pelibatan orang Tua dalam Program Sekolah di TK Khalifah Wirobrajan Yogyakarta.

Peran serta orang tua menjadi komite sekolah adalah karena dorongan untuk bisa mengawasi pelayanan yang diberikan oleh sekolah. Orang tua mengontrol apakah pelayanan itu sudah sesuai dengan ketentuan peraturan perundang-undangan ataukah menyimpang. Orang tua dapat memberikan pertimbangan dalam penentuan dan pelaksanaan kebijakan pendidikan terkait kebijakan dan program sekolah. Keluhan, 
saran, kritik tentang pendidikan ditampung untuk disampaikan kepada sekolah guna dicari tindaklanjut sebagai apresiasi. Orang tua bersedia menjadi anggota komite sekolah karena hal tersebut dan dengan tujuan akhir untuk meningkatkan kualitas sekolah. Hal ini sejalan dengan penelitian Juwita (2017) yang berjudul Peranan Orang Tua sebagai Anggota Komite di Sekolah Menengah Atas (SMA) Kristen Palangka Raya.

Peran selanjutnya adalah sebagai pendamping kegiatan ekstrakurikuler. Orang tua yang juga sekaligus alumni dari SD negeri 3 Jatiluhur yang mempunyai keahlian, membantu menjadi pendamping kegiatan ekstrakurikuler. Hal ini untuk memotivasi anak untuk ikut serta dalam kegiatan ekstrakurikuler, juga untuk mengawasi kegiatan anak setelah jam sekolah selesai. Mereka melakukan hal tersebut karena juga merasa ikut bertanggung jawab atas kelangsungan pendidikan anak-anak mereka.

Orang tua juga berperan aktif dalam kegiatan yang diselenggarakan oleh komite, seperti halnya menghias kelas agar ruang kelas tampak lebih menarik. Orang tua juga berperan aktif dalam penguatan pendidikan karakter anak, hal ini bisa dilihat dari dukungan orang tua ketika mengantar siswa sampai ke sekolah sebelum bel masuk berbunyi. Orang tua juga mengijinkan anaknya diikutkan dalam berbagai kegiatan perlombaan maupun pertandingan yang menanamkan pendidikan karakter.

\section{SIMPULAN}

Orang tua sesungguhnya memiliki peran yang sangat besar dalam pendidikan anak mereka. Keberhasilan pendidikan anak sangat bergantung kepada peran orang tua. Peran serta orang tua dalam mendidik anak adalah kunci keberhasilan orang tua. Pendidikan yang diperoleh anak di sekolah juga memerlukan peran serta dari orang tua. Peran serta orang tua merupakan keterlibatan orang tua dalam berbagai kegiatan di sekolah dalam rangka memberikan dukungan terhadap kegiatan belajar anak di sekolah.

Bentuk peran serta orang tua murid yang telah dijalankan oleh SD Negeri 3 Jatiluhur sesuai dengan Bab III Pasal 6 Permendikbud Nomor 30 tahun 2017 diantaranya adalah: (1) menghadiri pertemuan yang diselenggarakan oleh sekolah; (2) mengikuti kelas orang tua/wali; (3) menjadi anggota komite sekolah; (4) sebagai pendamping kegiatan ekstrakurikuler; (5) berperan aktif dalam kegiatan yang diselenggarakan oleh komite sekolah; (6) berperan aktif dalam kegiatan Penguatan Pendidikan Karakter Anak di sekolah.

\section{DAFTAR PUSTAKA}

https://www.kompasiana.com/hadisumantri3928/5b5294a46ddcae31f2675ae6/pentingn ya-peran-keluarga-dan-masyarakat-pada-pendidikan-anak-di-sekolah?page=all diakses pada tanggal 29 September 2019 pukul 12.30

https://www.kompasiana.com/www.stevanmanihuruk.com/5b72af17bde5750f00141173/pelibatan-keluarga-menghadapitantangan-penyelenggaraan-pendidikan-di-era-kekinian?page=all diakses pada tanggal 29 September 2019 pukul 13.00

Ihat Hatimah. (2014). Keterlibatan Keluarga dalam Kegiatan di Sekolah dalam perspektif Kemitraan. Pedagogia: Jurnal IImu Pendidikan

Juwita Ratna. (2017). Peranan Orang Tua sebagai Anggota Komite di Sekolah Menengah Atas (SMA) Kristen Palangka Raya. Jurnal Meretas Jilid 4, Nomor 4

Karmawan dkk. (2012). Peranan Keluarga dalam Meningkatkan Motivasi Belajar Siswa (Studi Kasus di SD Negeri 22 Mengkudu Kecamatan Teluk Keramat Kabupaten Sambas) Jurnal Tesis PMIS-UNTAN-PSS

Murwatiningsih, N. M. (2017). Pelibatan Orang Tua pada Pendidikan Anak di SD Sains Islam Al Farabi Sumber Cirebon. Educational Management, 100 - 108. 
Novrinda. (2017). Peran Orang Tua dalam Pendidikan Anak Usia Dini Ditinjau dari Latar Belakang Pendidikan. Jurnal Potensia, PG-PAUD FKIP UNIB, Vo. 2 No. 1.

Prabhawani. (2016). Pelibatan Orang Tua dalam program Sekolah di TK Khalifaj Wiribrajan Yogyakarta. Jurnal Pendidikan Guru Pendidikan Anak Usia Dini Edisi 2 Tahun ke-5

Scribner, J. D., Young, M. D., \& Pedroza, A. (1999). Building collaborative relationships with parents. In J. D. Scribner \& A. ParedesScribner (Eds.), (pp 36-60). New York: Teachers College Press. Lessons from high-performing Hispanic schools: Creating learning communities

Sukiman. (2017). Kebijakan Teknis pelibatan Keluarga dalam penyelenggaraan Pendidikan ( Permendikbud No 30/2017)

Kemdikbud. (2016). Petunjuk Teknis Kemitraan Sekolah Dasar dengan Keluarga dan Masyarakat. Kemdikbud Ditjen PAUD dan Dikmas Direktorat Pembinaan Pendidikan Keluarga.

Kemdikbud. (2017). Permendikbud Nomor 30 Tahun 2017 tentang Pelibatan Keluarga Pada Penyelenggaraan Pendidikan 